\title{
Weakened Activity of Starved Ammonia-oxidizing Bacteria by the Presence of Pre-activated Nitrobacter winogradskyi
}

\author{
HENDRIKUS J. LAANBROEK ${ }^{1 *}$ and MARIE-JOSÉ BÄR-GILISSEN ${ }^{1}$ \\ ${ }^{1}$ Department of Microbial Ecology, NIOO-KNAW Centre for Limnology, Rijksstraatweg 6, 3631 AC \\ Nieuwersluis, The Netherlands
}

(Received March 23, 2002-Accepted July 12, 2002)

\begin{abstract}
Ammonia-oxidizing bacteria are able to maintain a high oxidizing potential during starvation. Nitrite has a short-lasting stimulatory effect on the oxidation of ammonia after starvation when supplied simultaneously with fresh ammonium ${ }^{9}$. To examine whether nitrite-oxidizing bacteria as partners in naturally occurring nitrifying communities interfere with this stimulatory effect of nitrite, mixed culture experiments were performed in sand slurries. Following the consumption of ammonium, these mixed cultures were starved for 4 months in their own medium. After the starvation period, ammonium was supplied. In contrast to the former experiments in monocultures of Nitrosomonas europaea, no short-lasting peak in ammonium oxidation activity was observed in the presence of nitrite-oxidizing cells. When these nitrite-oxidizing cells had been pre-activated with $5 \mathrm{mM}$ nitrite one week before ammonium was supplied to the starving cultures, ammonia-oxidizing activity was weakened for up to four days, depending on the culture examined. The possibility that ammonia-oxidizing cells are repressed in the presence of nitrite-oxidizing cells in natural environments such as nitrifying biofilms is discussed.
\end{abstract}

Key words: Nitrosomonas, Nitrosospira, Nitrobacter, nitrification, inhibition

Ammonium can be used by a large number of both proand eukaryotic organisms. It can be oxidised to nitrite by chemolithotrophic bacteria for the generation of energy, but it can also be assimilated into cellular components by autotrophic and heterotrophic organisms. Hence, under conditions where ammonium is scree, a large number of organisms will compete for this ion. Under such conditions, the ammonia-oxidizing activity of cells of the chemolithotrophic Nitrosomonas europaea is repressed by the presence of ammonium-assimilating heterotrophic bacteria and/or plant roots ${ }^{20)}$. Ammonium oxidation in the field is also repressed during the growing season of the wetland plant Glyceria maxima ${ }^{2}$. Hence, ammonia-oxidizing bacteria have to withstand longer periods of starvation for ammonium. It has been shown that pure cultures of different ammonia-oxidizing bacteria are able to preserve their ammonia-oxidizing activities for longer periods in the ab-

\footnotetext{
* Corresponding author; E-mail: laanbroek@cl.nioo.knaw.nl, Tel: +31-294-239336, Fax: +31-294-232224
}

sence of ammonium ${ }^{4-7,18,21)}$. Recently, it was also shown that ammonium-starved cells of $N$. europaea are stimulated by the presence of nitrite when fresh ammonium is supplied ${ }^{9)}$. However, such stimulation lasted only 4-6 hours, after which ammonia oxidation rates again became independent of the presence of nitrite. According to Schmidt et al. ${ }^{15)}$, NO and $\mathrm{NO}_{2}$ are both involved in the aerobic oxidation of ammonium. Starved cells might be deprived of these gaseous compounds, which may delay a quick recovery from starvation after the addition of fresh ammonium. Since the reduction of nitrite to NO has also been shown to occur in $N$. europaea $^{1,13,14)}$, nitrite may serve as a source of NO in ammonia-starved cells as suggested by Laanbroek et al. ${ }^{9}$. Cells of $N$. europaea growing in continuous culture under ammonium- and oxygen-limited conditions produced NO and $\mathrm{N}_{2} \mathrm{O}$ in addition to nitrite ${ }^{8}$. However, in the presence of actively nitrite-oxidizing cells of Nitrobacter winogradskyi, ammonium- and oxygen-limited cells of $N$. europaea produced only very small amounts of these gases. Hence, cells of $N$. winogradskyi had a repressive effect on the production 
of $\mathrm{NO}$ and $\mathrm{N}_{2} \mathrm{O}$ by ammonium-limited growing cells, probably by taking nitrite away from the ammonia-oxidizing cells. Alternatively, active cells of $N$. winogradskyi could have consumed $\mathrm{NO}$ and $\mathrm{NO}_{2}$ themselves. As discussed by Laanbroek et al. ${ }^{9}$, the stimulation of ammonia oxidation in ammonia-starved cells of $N$. europaea in the presence of nitrite could therefore be a phenomenon of cells growing in pure culture. In mixed cultures or consortia of ammonia- and nitrite-oxidizing bacteria, which are more representative of natural conditions, stimulation by nitrite might never occur. The nitrite-oxidizing cells may even repress the recovery from ammonia starvation by taking the gases away.

In the present paper, we present the results of slurry experiments aimed at elucidating the effect the presence of $N$. winogradskyi has on the recovery of ammonia oxidation by ammonia-starved cells after addition of fresh ammonium. Since the nitrite-oxidizing cells are starved for nitrite in ammonia-starved mixed cultures of ammonia- plus nitriteoxidizing cells, consumption of nitrite, $\mathrm{NO}$ and $\mathrm{NO}_{2}$ by $N$. winogradskyi might be delayed in relation to ammonia oxidation after the addition of fresh ammonium and might consequently not affect the oxidation. To allow the nitrite-oxidizing cells a better start and to prevent the intermediate accumulation of nitrite, some of the mixed cultures received nitrite one week before the fresh ammonium. Hence, both starved and pre-activated cells of $N$. winogradskyi were used in the experiments, which involved starved cells of $N$. europaea, Nitrosomonas eutropha and Nitrosospira briensis.

\section{Materials and Methods}

\section{Strains}

Nitrosomonas europaea strain ATCC 19781, Nitrosomonas eutropha strain Nm 57 and Nitrosospira briensis strain ATCC 25971 were used as ammonia-oxidizing species and Nitrobacter winogradskyi strain ATTC 25391 as the nitrite-oxidizing species. $N$. eutropha was kindly supplied by Dr. Koops, Department of Microbiology, University of Hamburg, Germany.

\section{Culture and starvation conditions}

Cells were grown in non-shaken slurries containing $4 \mathrm{~g}$ of river sand in $20 \mathrm{ml}$ of Hepes-buffered mineral medium at 26 ${ }^{\circ} \mathrm{C}$ in the dark. Mineral medium contained per liter; $330 \mathrm{mg}$ of $\left(\mathrm{NH}_{4}\right)_{2} \mathrm{SO}_{4}, 585 \mathrm{mg}$ of $\mathrm{NaCl}, 55 \mathrm{mg}$ of $\mathrm{KH}_{2} \mathrm{PO}_{4}, 49 \mathrm{mg}$ of $\mathrm{MgSO}_{4} .7 \mathrm{H}_{2} \mathrm{O}, 147 \mathrm{mg}$ of $\mathrm{CaCl}_{2} .2 \mathrm{H}_{2} \mathrm{O}, 75 \mathrm{mg}$ of $\mathrm{KCl}, 10 \mathrm{~g}$ of Hepes and $1 \mathrm{ml}$ of trace elements solution according to
Verhagen and Laanbroek ${ }^{19)}$. Bromothymolblue $(3.2 \mathrm{mg} / \mathrm{l})$ was added from a $0.04 \%$ stock solution as an indicator of $\mathrm{pH}$. The $\mathrm{pH}$ was adjusted with $1 \mathrm{~N} \mathrm{NaOH}$ to 7.7 before autoclaving. Before inoculation, the sand slurries were autoclaved and cooled to room temperature. After 24 hours, the slurries were decanted and supplied with fresh mineral medium and autoclaved again. In total, three subsequent cycles of autoclaving, cooling and decanting were applied. Active pure cultures of nitrifying bacteria were used for inoculation of the sand slurries. These cultures had been grown in mineral medium containing either $2,5 \mathrm{mM}\left(\mathrm{NH}_{4}\right)_{2} \mathrm{SO}_{4}$ or $5 \mathrm{mM}$ $\mathrm{NaNO}_{2}$. Usually within a week after inoculation, the ammonium was converted to nitrate and the sand slurries were decanted and fresh mineral medium was added. This subculturing was repeated three times. The use of sand cultures facilitated the axenic replacement of spent medium by fresh medium without the loss of a large portion of the cells. On average, $32 \%$ of the cells and $8 \%$ of the medium remained in the culture after decanting. After three rounds of subculturing in fresh mineral medium, the sand cultures were stored at $12^{\circ} \mathrm{C}$ in the dark without agitation in their own spent medium, which contained $5 \mathrm{mM}$ nitrate.

\section{Resuscitation experiments}

After 4 months of ammonium starvation, the sand cultures were decanted, supplied with fresh mineral medium with $5 \mathrm{mM}$ ammonium and incubated at $26^{\circ} \mathrm{C}$ in the dark at $150 \mathrm{rpm}$. During the resuscitation experiments, samples of supernatant were regularly taken for measurements of nitrite and nitrate concentrations, starting thirty minutes after the addition of fresh medium. Measurements performed in the presence of excess ammonium were considered to yield potential or maximal oxidation rates. The experiments were performed five times for $N$. europaea and twice for $N$. eutropha and $N$. briensis, respectively.

\section{Chemical analyses}

Samples used for the determination of nitrite and nitrate were centrifuged at $15000 \mathrm{~g}$ in an EBA 12 table centrifuge for $10 \mathrm{~min}$. Analyses of mineral nitrogen occurred immediately or within 24 hours of storage at $-20^{\circ} \mathrm{C}$. Nitrite and nitrate concentrations were determined by High-Pressure Liquid Chromatography according to Bollmann and Laanbroek $^{3)}$.

\section{Results}

The effect of $N$. winogradskyi on $N$. europaea

In the slurry cultures with $N$. europaea and $N$. winograd- 
N. europaea

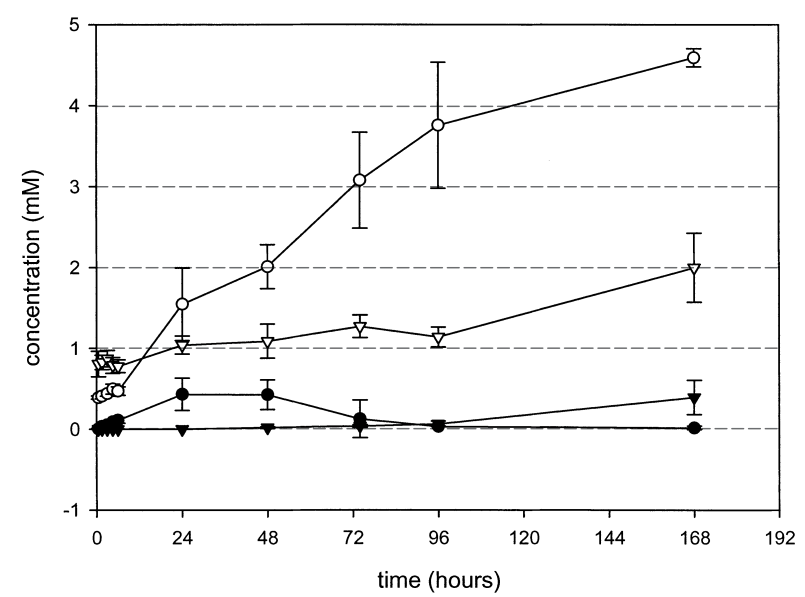

Fig. 1. Changes in nitrite (closed symbols) and nitrite plus nitrate (open symbols) concentrations after addition of $5 \mathrm{mM}$ ammonium to mixed cultures of Nitrosomonas europaea and Nitrobacter winogradskyi after a starvation period of 4 months in spent medium containing $5 \mathrm{mM}$ nitrate. Half of the cultures (triangles) received $5 \mathrm{mM}$ nitrite one week before the addition of ammonium, the other half (circles) did not. Presented are the means and standard deviations $(n=5)$.

skyi starved for 11 weeks, ammonium oxidation started immediately after addition of fresh medium with $5 \mathrm{mM}$ ammonium (Fig. 1). However, the excessive oxidation that had been encountered during the initial 6 hours in starved, pure cultures of $N$. europaea ${ }^{9}$ ) was not observed in these mixed cultures of ammonia- and nitrite-oxidizing bacteria. In contrast, the ammonia oxidation rate was rather low during the first 6 hours after addition of fresh ammonium. Nitrite accumulated to a level of $0.4 \mathrm{mM}$ during the first 24 hours after ammonium addition. After 1 day the oxidation of nitrite to nitrate could be observed and after 4 days nitrite had disappeared from the culture.

Starved mixed cultures supplied with $5 \mathrm{mM}$ nitrite oxidised this compound within 5 days to nitrate after a starvation period of 11 weeks (not shown). In these cultures that had been pre-treated with $5 \mathrm{mM}$ nitrite, the sum of nitrite plus nitrate concentrations increased slowly after addition of fresh medium with ammonium, which indicated a low ammonia-oxidizing activity (Fig. 1). During the incubation period, a very minor production of nitrite was observed during the first days. A more significant production of nitrite started after 4 days.

\section{The effect of $N$. winogradskyi on $N$. eutropha}

In the starved, mixed cultures with non-activated cells of
N. eutropha

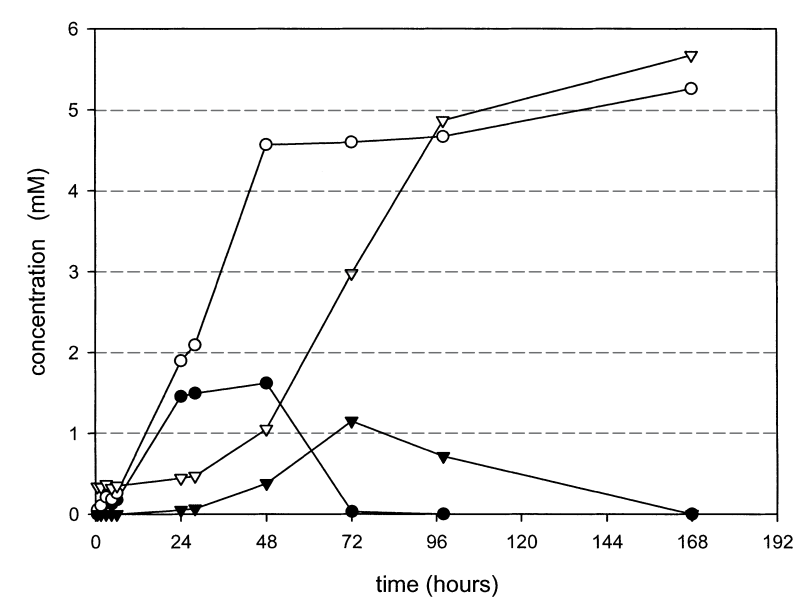

Fig. 2. Changes in nitrite (closed symbols) and nitrite plus nitrate (open symbols) concentrations after addition of $5 \mathrm{mM}$ ammonium to mixed cultures of Nitrosomonas eutropha and Nitrobacter winogradskyi after a starvation period of 4 months in spent medium containing $5 \mathrm{mM}$ nitrate. Half of the cultures (triangles) received $5 \mathrm{mM}$ nitrite one week before the addition of ammonium, the other half (circles) did not. Presented are the means $(n=2)$.

$N$. winogradskyi, ammonium oxidation started immediately after the addition of fresh medium with $5 \mathrm{mM}$ ammonium (Fig. 2). However, as with starved $N$. europaea cells, excessive ammonia oxidation was not observed during the first hours after the application of fresh ammonium. Two days after the addition of fresh ammonium, $91 \%$ of this substrate was already oxidised to nitrite and nitrate. During the initial incubation period, nitrite started to accumulate to a concentration of $1.5 \mathrm{mM}$, but after one day a clear oxidation of nitrite to nitrate was observed.

In the parallel slurries with pre-activated cells of $N$. winogradskyi, ammonium oxidation started only after 24 hours as indicated by the increase in the sum of nitrite plus nitrate concentrations (Fig. 2). After 4 days, 97\% of the supplied ammonium had been converted to nitrite plus nitrate. During the first day of incubation, no oxidation of nitrite could be observed. During day 2 and 3 after the addition of fresh ammonium, a slight oxidation of nitrite could be observed and after 3 days a clear oxidation of nitrite occurred.

\section{The effect of $N$. winogradskyi on $N$. briensis}

Finally the experiments were repeated with cells of $N$. briensis as the ammonia-oxidizing component of the mixed nitrifying community. In the slurries with non-activated cells of $N$. winogradskyi, ammonium oxidation started at a 
N. briensis

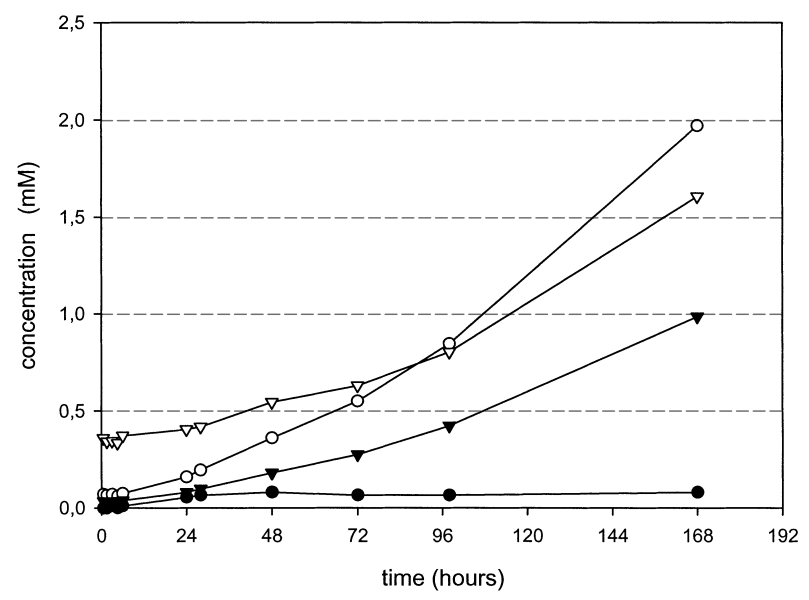

Fig. 3. Changes in nitrite (closed symbols) and nitrite plus nitrate (open symbols) concentrations after addition of $5 \mathrm{mM}$ ammonium to mixed cultures of Nitrosospira briensis and Nitrobacter winogradskyi after a starvation period of 4 months in spent medium containing $5 \mathrm{mM}$ nitrate. Half of the cultures (triangles) received $5 \mathrm{mM}$ nitrite one week before the addition of ammonium, the other half (circles) did not. Presented are the means $(n=2)$.

low but steady rate immediately after addition of fresh medium with $5 \mathrm{mM}$ ammonium (Fig. 3). During the first day after addition of fresh ammonium, the nitrite concentration started to increase to a level of $65 \mu \mathrm{M}$ and remained surprisingly at a constant level of $65-80 \mu \mathrm{M}$ during the whole incubation period.

In the parallel mixed cultures that contained pre-activated cells of $N$. winogradskyi, a weakened ammonia-oxidizing activity was observed during 4 days after the supply of fresh medium with $5 \mathrm{mM}$ ammonium (Fig. 3). After 4 days, an increase in the ammonia-oxidizing activity was observed. Surprisingly, hardly any nitrite oxidation was observed during the whole incubation period in these cultures that had been pre-activated with $5 \mathrm{mM}$ nitrite one week before fresh medium with ammonium was added.

\section{Discussion}

The presence of $N$. winogradskyi in mixed cultures with ammonia-oxidizing bacteria had an effect on the ammoniaoxidizing activity, especially in those cultures that had been pre-treated with $5 \mathrm{mM}$ nitrite one week before fresh medium with $5 \mathrm{mM}$ ammonium was added. In the pre-treated cultures containing starved cells of $N$. eutropha, ammonium oxidation was delayed by two days compared with the non pre-treated cultures containing $N$. eutropha. In the pre-treat- ed cultures with starved cells of $N$. europaea or $N$. briensis, the oxidation rate of ammonium never reached the level of the non pre-treated controls during the incubation period. The observed differences between the ammonia-oxidizing species with respect to the start of ammonia oxidation may point to differences in physiology. These differences are not known since most physiological studies of autotrophic ammonia-oxidizing bacteria have been restricted to $N$. europaea. The activation of nitrite-oxidizing cells by addition of $5 \mathrm{mM}$ nitrite had thus a weakening effect on the ammonia-oxidizing potential of ammonia-starved cells by a yet unknown mechanism. A delay of 3 days in ammonia oxidation after an initial active period of 24 hours after addition of fresh ammonium had been noted before ${ }^{4)}$. Repression of ammonia-oxidizing activity after an initial period of high activity occurred when cells from oxic soil and sand columns that had been supplied continuously with growth-limiting amounts of ammonium, received suddenly an excess amount of ammonium. In these ammonia-limited cells, the repression of activity was due to the inactivation of enzymes, since the ammonia-oxidizing activity did not recover in the presence of chloramphenicol. The delay in ammonia oxidation after addition of fresh ammonium in the presence of active cells of $N$. winogradskyi resembles the increased lag time observed with monocultures of $N$. eutropha after switching from anoxic, denitrifying conditions in the absence of ammonium to oxic conditions in the presence of ammonium ${ }^{16)}$. Addition of $\mathrm{NO}_{2}$ shortened the lag time significantly by 6 days. Up to 2 ppm NO were detectable in the gas atmosphere above the culture during the first hours of ammonia oxidation. Low concentrations of DMPS (2,3-Dimercapto-1-propane-sulfonic acid), which is a scavenger of NO like $N$. winogradskyi, inhibited aerobic ammonia oxidation activity in $\mathrm{NO}$ - and $\mathrm{NO}_{2}$-free atmospheres ${ }^{16)}$. $\mathrm{NO}$ is assumed to provide the cell with $\mathrm{NO}_{2}$ which functions as the oxidant of ammonia oxidation ${ }^{15}$. Hence, by scavenging traces of NO that escape from the cells that started to oxidise ammonia, active cells of $N$. winogradskyi might have prevented the appearance of excessive, short-lasting ammonia oxidation as obtained with cells of $N$. europaea that had been starved for ammonium in monocultures after addition of fresh ammonium ${ }^{9}$. Much to our surprise, the behavior of the nitrite-oxidizing cells was dependent on the ammonia-oxidizing species present in the consortia of cells, especially in those cases where they had been pre-activated with $5 \mathrm{mM}$ nitrite one week before fresh medium with ammonium had been added. In the mixed cultures containing either $N$. eutropha or $N$. briensis, nitrite oxidation was low for 3-4 days, respectively, although these cells had 
oxidised $5 \mathrm{mM}$ nitrite just one week before. The mechanism for such a repression of nitrite oxidation is unknown. In the mixed cultures with starved cells of $N$. europaea and pre-activated cells of $N$. winogradskyi, the retarded activity of the nitrite-oxidizing cells had apparently been masked by the overall low nitrite-producing activity of $N$. europaea during the first 4 days after addition of fresh ammonium.

In conclusion, the presence of $N$. winogradskyi had a weakening effect on the reaction of ammonia-oxidizing cells to fresh ammonium after a prolonged period of starvation, both with respect to the absence of the high, short-lasting peak in ammonia-oxidizing activity observed in monocultures of $N$. europaea as well as in relation to the overall ammonia oxidation rates. A nitrite flux without ammonium is hard to envisage in oxic environments where the supply of nitrite is dependent on the activity of the ammonia-oxidizing bacteria. However, under suboxic conditions as may occur in nitrifying biofilms, nitrite might accumulate under certain conditions $^{12,17)}$. The accumulation of nitrite depends on the relative supplies of ammonium and oxygen as well as on the relative abundances of the ammonia- and nitrite-oxidizing cells. When the supply of ammonium exceeds the input of oxygen and the biomass of ammonia-oxidizing cells is large enough to deal with the supply of ammonium plus oxygen, then the remaining oxygen will not be sufficient to oxidise all the nitrite produced and nitrite accumulates ${ }^{12,17}$. However, when for some reason the biomass of the nitriteoxidizing cells increases relative to the ammonia-oxidizing cells, as observed for the deeper layers of nitrifying biofilms, then ammonium and not nitrite accumulates. Hence in these biofilms, the accumulation of ammonium and nitrite is dependent on the relative biomasses of ammonia- and nitrite-oxidizing cells, respectively. In competition for a common growth-limiting substrate, such as oxygen for the ammonia- and nitrite-oxidizing bacteria, the ratio between the maximal consumption rate $\left(\mathrm{V}_{\max }\right)$ and the affinity constant $\left(\mathrm{K}_{\mathrm{m}}\right)$ determines the outcome of the competition. This has been demonstrated for the consortium of $N$. europaea and $N$. winogradskyi ${ }^{10)}$. Only an increase in the biomass of nitrite-oxidizing cells relative to the biomass of ammonia-oxidizing cells, which can be due to the simultaneous oxidation of small organic molecules by the nitrite-oxidizing cells, will compensate for the apparently low affinity for oxygen of Nitrobacter species ${ }^{11}$. However, notwithstanding the accumulation of nitrite in spatially structured biofilms, it is hard to imagine that nitrite-oxidizing bacteria will interfere with the recovery of ammoniaoxidizing cells after starvation due to the different active locations for ammonia- and nitrite-oxidizing cells within the biofilm.

\section{Acknowledgements}

We would like to thank Dr. Paul Bodelier for valuable discussions and two unknown reviewers for their constructive comments.

\section{References}

1) Bock, E., I. Schmidt, R. Stüven and D. Zart. 1995. Nitrogen loss caused by denitrifying Nitrosomonas cells using ammonia or hydrogen as electron donors as nitrite as electron acceptor. Arch. Microbiol. 163: 16-20.

2) Bodelier, P.L.E., J.A. Libochant, C.W.P.M. Blom and H.J. Laanbroek. 1996. Dynamics of nitrification and denitrification in root-oxygenated sediments and adaptation of ammonia-oxidizing bacteria to low oxygen or anoxic habitats. Appl. Environm. Microbiol. 62: 4100-4107.

3) Bollmann A. and H.J. Laanbroek. 2001. Continuous culture enrichments of ammonia-oxidizing bacteria at low ammonium concentrations. FEMS Microbiol. Ecol. 37: 211-221.

4) Gerards, S., H. Duyts and H.J. Laanbroek. 1998. Ammonium-induced inhibition of ammonium-starved Nitrosomonas europaea cells in soil and sand slurries. FEMS Microbiol. Ecol. 26: 269280.

5) Johnstone, B.H. and R.D. Jones. 1988a. Physiological effects of long-term energy-source deprivation on the survival of a marine chemolithotrophic ammonium-oxidizing bacterium. Mar. Ecol. Prog. Ser. 49: 295-303.

6) Johnstone, B.H. and R.D. Jones. 1988b. Recovery of a marine chemolithotrophic ammonium-oxidizing bacterium from longterm energy-source deprivation. Can. J. Microbiol. 34: 13471350.

7) Jones, R.D. and R.Y. Morita. 1985. Survival of a marine ammonia oxidizer under energy-source deprivation. Mar. Ecol. Prog. Ser. 26: 175-179.

8) Kester, R.A., W. de Boer and H.J. Laanbroek. 1997. Production of $\mathrm{NO}$ and $\mathrm{N}_{2} \mathrm{O}$ by pure cultures of nitrifying and denitrifying bacteria during changes in aeration. Appl. Environm. Microbiol. 63: $3872-3877$

9) Laanbroek, H.J., M.-J. Bär-Gilissen and H.L. Hoogveld. 2002. Nitrite as stimulus for ammonium-starved Nitrosomonas europaea. Appl. Environm. Microbiol. 68: 1454-1457.

10) Laanbroek, H.J. and S. Gerards. 1993. Competition for limiting amounts of oxygen between Nitrosomonas europaea and Nitrobacter winogradskyi grown in mixed continuous cultures. Arch. Microbiol. 159: 453-459.

11) Laanbroek, H.J., S. Gerards and P.L.E. Bodelier. 1994. Oxygen consumption kinetics of Nitrosomonas europaea and Nitrobacter hamburgensis grown in mixed continuous cultures at different oxygen concentrations. Arch. Microbiol. 161: 156-162.

12) Okabe, S., H. Satoh and Y. Watanabe. 1999. In situ analysis of nitrifying biofilms as determined by in situ hybridisation and the use of microelectrodes. Appl. Environm. Microbiol. 65: 3182-3191.

13) Poth, M. 1986. Dinitrogen production from nitrite by a Nitrosomonas isolate. Appl. Environm. Microbiol. 52: 957-959. 
14) Poth, M. and D.D. Focht. $1985 .{ }^{15} \mathrm{~N}$ Kinetic analysis of $\mathrm{N}_{2} \mathrm{O}$ production by Nitrosomonas europaea: an examination of nitrifier nitrification. Appl. Environm. Microbiol. 49: 1134-1141.

15) Schmidt I., E. Bock and M.J.M. Jetten. 2001a. Ammonia oxidation by Nitrosomonas eutropha with $\mathrm{NO}_{2}$ as oxidant is not inhibited by acetylene. Microbiology 147: 2247-2253.

16) Schmidt I., D. Zart and E. Bock. 2001b. Gaseous $\mathrm{NO}_{2}$ as a regulator for ammonia oxidation of Nitrosomonas eutropha. Ant van Leeuwenhoek Int J. Gen. Mol. Microbiol. 79: 311-318.

17) Schramm, A., D. de Beer, J.C. van den Heuvel, S. Ottengraf and R. Ammann. 1999. Microscale distribution of populations and activities of Nitrosospira and Nitrospira spp. along a macroscale gradient in a nitrifying bioreactor: Quantification by in situ hybridisation and the use of microsensors. Appl. Environm. Microbiol. 65: 3690-3696.

18) Tappe, W., A. Laverman, M. Bohland, M. Braster, S. Rittershaus,
J. Groeneweg and H.W. van Verseveld. 1999. Maintenance energy demand and starvation recovery dynamics of Nitrosomonas europaea and Nitrobacter winogradskyi cultivated in a retentostat with complete biomass retention. Appl. Environm. Microbiol. 65 : 2471-2477.

19) Verhagen, F.J.M. and H.J. Laanbroek. 1991. Competition for ammonium between nitrifying and heterotrophic bacteria in energy limited chemostats. Appl. Environm. Microbiol. 57: 3255-3263.

20) Verhagen, F.J.M., H.J. Laanbroek and J.W. Woldendorp. 1995. Competition for ammonium between nitrifying, heterotrophic bacteria and plant roots and effects of grazing by protozoa. Plant. Soil. 170: 241-250.

21) Wilhelm, R., A. Abeliovich and A. Nejidat. 1998. Effect of longterm ammonia starvation on the oxidation of ammonia and hydroxylamine by Nitrosomonas europaea. J. Biochem. 124: 811-815. 